\title{
Corrosion Behavior of Alloy 22 in Oxalic Acid and Sodium Chloride Solutions
}

S.D. Day, M.T. Whalen, K.J. King, G.A. Hust, L.L. Wong, J.C. Estill, R.B. Rebak

This article was submitted to 2003 American Society of Mechanical Engineers Pressure Vessels and Piping Conference, Cleveland, $\mathrm{OH}$, July 20-24, 2003

\section{June 24, 2003}

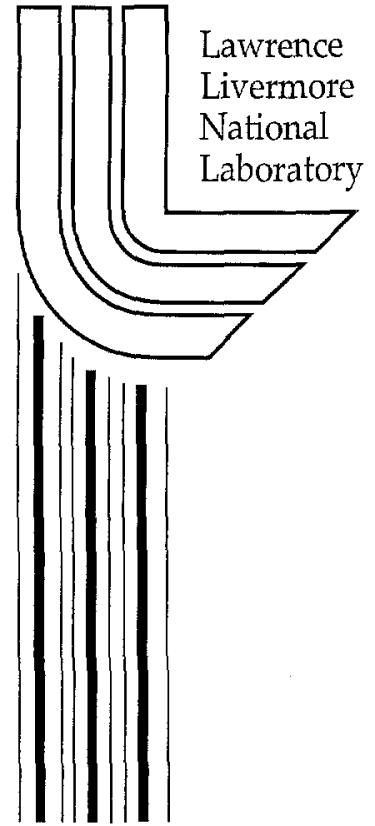




\section{DISCLAIMER}

This document was prepared as an account of work sponsored by an agency of the United States Government. Neither the United States Government nor the University of California nor any of their employees, makes any warranty, express or implied, or assumes any legal liability or responsibility for the accuracy, completeness, or usefulness of any information, apparatus, product, or process disclosed, or represents that its use would not infringe privately owned rights. Reference herein to any specific commercial product, process, or service by trade name, trademark, manufacturer, or otherwise, does not necessarily constitute or imply its endorsement, recommendation, or favoring by the United States Government or the University of California. The views and opinions of authors expressed herein do not necessarily state or reflect those of the United States Government or the University of California, and shall not be used for advertising or product endorsement purposes.

This is a preprint of a paper intended for publication in a journal or proceedings. Since changes may be made before publication, this preprint is made available with the understanding that it will not be cited or reproduced without the permission of the author.

This report has been reproduced directly from the best available copy.

Available electronically at http://www.doc.gov/bridge

Available for a processing fee to U.S. Department of Energy

And its contractors in paper from

U.S. Department of Energy

Office of Scientific and Technical Information

P.O. Box 62

Oak Ridge, TN 37831-0062

Telephone: (865) 576-8401

Facsimile: (865) 576-5728

E-mail: reports@adonis.osti.gov

Available for the sale to the public from

U.S. Department of Commerce

National Technical Information Service

5285 Port Royal Road

Springfield, VA 22161

Telephone: (800) 553-6847

Facsimile: (703) 605-6900

E-mail: orders@ntis.fedworld.gov

Online ordering: http://www.ntis.gov/ordering.htm

\section{OR}

Lawrence Livermore National Laboratory Technical Information Department's Digital Library

http://www.llnl.gov/tid/Library.html 
Paper prepared for presentation to the 2003 American Society of Mechanical Engineers Pressure Vessels and Piping Conference, 20-24 July 2003 in Cleveland. The paper will also be sent for publication to Corrosion Magazine.

\title{
Corrosion Behavior of Alloy 22 in Oxalic Acid and Sodium Chloride Solutions
}

\author{
S. Daniel Day, Michael T. Whalen, Kenneth J. King, Gary A. Hust, Lana L. Wong, \\ John C. Estill and Raúl B. Rebak \\ Lawrence Livermore National Laboratory, Livermore, CA 94550
}

\begin{abstract}
Nickel based Alloy 22 (N06022) is extensively used in aggressive industrial applications, especially due to its resistance to localized corrosion and stress corrosion cracking in high chloride environments. The purpose of this work was to characterize the anodic behavior of Alloy 22 in oxalic acid solution and to compare its behavior to sodium chloride $(\mathrm{NaCl})$ solutions. Standard electrochemical tests such as polarization resistance and cyclic polarization were used. Results show that the corrosion rate of Alloy 22 in oxalic acid solutions increased rapidly as the temperature and the acid concentration increased. Extrapolation studies show that even at a concentration of $10^{-4} \mathrm{M}$ oxalic acid, the corrosion rate of Alloy 22 would be higher in oxalic acid than in $1 \mathrm{M} \mathrm{NaCl}$ solution. Alloy 22 was not susceptible to localized corrosion in oxalic acid solutions. Cyclic polarization tests in $1 \mathrm{M} \mathrm{NaCl}$ showed that Alloy 22 was susceptible to crevice corrosion at $90^{\circ} \mathrm{C}$ but was not susceptible at $60^{\circ} \mathrm{C}$.
\end{abstract}

\section{INTRODUCTION}

Nickel ( $\mathrm{Ni}$ ) can be alloyed with metallic elements to produce several types or family of alloys [1]. One of these families is the Nickel-Chromium-Molybdenum (Ni-Cr-Mo) or the Alloy C-type. Alloys such as C-276 (N10276), C-4 (N06455), alloy 625 (N06625), Alloy 22 (N06022), Alloy 59 (N06059), Alloy 2000 (N06200) and Alloy 686 (N06686) belong to the $\mathrm{Ni}$-Cr-Mo group. Alloy 22 contains by weight $22 \%$ chromium $(\mathrm{Cr}), 13 \%$ molybdenum (Mo), $3 \%$ tungsten (W) and approximately $3 \%$ iron (Fe). Alloy 22 was commercially designed to resist the most aggressive industrial applications, offering a low general corrosion rate both under oxidizing and reducing conditions. Under oxidizing and acidic conditions $\mathrm{Cr}$ exerts its beneficial effect in the alloy. Under reducing conditions the most beneficial alloying elements are Mo and W, which offer a low current for hydrogen discharge [1]. Moreover, due to its balanced content in $\mathrm{Cr}$, Mo and W, Alloy 22 is used extensively in hot chloride containing environments where austenitic stainless steels may fail by pitting corrosion and stress corrosion cracking (SCC) $[1,2]$. 
Alloy 22 is the material selected for the fabrication of the outer shell of the nuclear waste containers for the Yucca Mountain site [3,4]. Several papers have been published recently describing the general and localized corrosion behavior of Alloy 22 regarding its application for the nuclear waste containers [5-14]. Some of these studies included the characterization of Alloy 22 to localized corrosion in chloride solutions such as in lithium chloride ( $\mathrm{LiCl})$ [5], sodium chloride $(\mathrm{NaCl})$ [12-13] and calcium chloride $\left(\mathrm{CaCl}_{2}\right)$ [6-8]. It has also been reported that the addition of nitrate to a chloride-containing environment, decreases the susceptibility of Alloy 22 to localized attack $[4-6,13]$. Very little is known on the corrosion behavior of Alloy 22 in organic acids [1].

The objective of the current study was to use electrochemical methods and parameters to systematically assess the corrosion behavior of Alloy 22 (N06022) in oxalic acid solutions as compared to the behavior in sodium chloride solutions. Oxalic acid or ethanedioic ( $\mathrm{HOOCCOOH}$ or $\mathrm{H}_{2} \mathrm{O}_{4} \mathrm{C}_{2}$ ) is an organic acid widely used in the pharmaceutical industry as an intermediate or as a component. Oxalic acid is also used as bleaching agent in the textile industry, as a precipitation agent in the production of rare earths, as a rust remover, in water treatment, etc. Oxalic acid is one of the most aggressive alkane acids. Oxalic acid is slightly oxidizing with a $\mathrm{pKa} 1=1.23$ and a $\mathrm{pKa} 2=4.19$. Comparatively the dissociation constants of other organic acids are: $\mathrm{pKa}$ formic $=3.75, \mathrm{pKa}$ acetic $=4.75, \mathrm{pKa}$ propionic $=4.87, \mathrm{pKa}$ iso-butyric $=4.84, \mathrm{pKa} 1$ citric $=3.14, \mathrm{pKa} 2$ citric $=4.77$ and $\mathrm{pKa3}$ citric $=6.39$ [15]. Other aggressive organic acids include the aromatic acids picric $(\mathrm{pKa}=0.38)$ and o-phthalic $(\mathrm{pKa} 1$ $=2.89)[15]$.

Fungi and bacteria can decompose organic matter to produce organic acids [16-21]. Some of these organic acids include: oxalic, propionic, formic, citric, butyric, acetic, etc. For example, it is known that the fungus Aspergillus Niger can produce oxalic acid [16, 17]. Laboratory studies have shown that A. niger and Penicillium can produce small amounts of oxalic acid, in the order of $0.00018 \mathrm{M}$ (or $16 \mathrm{ppm}$ ) [16]. It must also be considered that this acid production must represent a high concentration condition, since the microorganisms were provided with nutrients (such as glucose). On the other hand, it is difficult to assess the concentration of the organic acid in a local spot, for example below biofilms. In short, it is not easy to predict with certainty what could be the concentration of oxalic acid in contact with a buried metallic container due to microbial activity. It is expected to be low (below $0.0001 \mathrm{M}$ ), first because the supply of organic matter is limited and second because oxalic acid reacts with some earth cations to form insoluble oxalate salts. For example, the solubility of calcium oxalate at $13^{\circ} \mathrm{C}$ is $0.00067 \mathrm{~g} / 100 \mathrm{cc}$ of water and at $95^{\circ} \mathrm{C}$ is 0.0014 $\mathrm{g} / 100 \mathrm{cc}$ of water [15]. These two amounts translate to $6.7 \mathrm{ppm}$ (or $0.000074 \mathrm{M}$ ) and $14 \mathrm{ppm}$ (or $0.00015 \mathrm{M}$ ). Indeed, one of the industrial applications of oxalic acid is to remove calcium from water in water treatment plants.

\section{EXPERIMENTAL}

Alloy 22 specimens were mainly prepared from wrought mill annealed plate stock. There were several heats of material used in this research. The basic chemical composition of Alloy 22 in weight percent was $-57 \% \mathrm{Ni}, 22 \% \mathrm{Cr}, 13 \% \mathrm{Mo}, 3 \% \mathrm{~W}, 3 \% \mathrm{Fe},<1 \% \mathrm{Co}, 0.14 \%$ 
Mn, $0.002 \% \mathrm{C}$, and $0.0001 \% \mathrm{~S}$. Alloy 22 was tested in the mill annealed (MA) or wrought condition and in the as-welded (ASW) condition. A couple of tests were carried out in MA plus thermally aged condition. The thermal aging was carried out at $700^{\circ} \mathrm{C}$ for $173 \mathrm{~h}$. This aging would have produced $\mathrm{mu}$ and $\mathrm{P}$ precipitates at the grain boundary and in the grain bodies of the alloy [22]. Most of the data analyzed here refer to the MA condition. Several different types of metallic specimens for electrochemical testing were used. Most of these specimens were multiple crevice assemblies (MCA), which were fabricated based on the washer for crevice forming described in ASTM G 48 [23]. The specimen MCA has been described before [5,7-8]. The welded MCA specimens were not all weld metal but they contained a narrow band of a gas tungsten arc weld seam. Other specimens were wire or prisms derived from specimens described in ASTM G 5 [23]. The prism specimen has also been described before [6]. The tested surface area of these specimens varied between $11 \mathrm{~cm}^{2}$ for the MCA to $1.8 \mathrm{~cm}^{2}$ for the wires. Most of the tested specimens had a finished grinding of abrasive paper number 600 and were degreased in acetone and treated ultrasonically for 5 minutes in de-ionized (DI) water 1 hour prior to testing.

Electrochemical tests were carried out in deaerated solutions of oxalic acid and sodium chloride $(\mathrm{NaCl})$. The $\mathrm{pH}$ of the $\mathrm{NaCl}$ solutions was approximately 6 to 6.5 and the $\mathrm{pH}$ of the oxalic acid solutions varied approximately from $\mathrm{pH}=0.5$ for the $1 \mathrm{M}$ oxalic acid, to $\mathrm{pH}=1.3$ for the $0.1 \mathrm{M}$ and to $\mathrm{pH}=2.1$ for the $0.01 \mathrm{M}$ oxalic acid concentration. Most of the test temperatures were $60^{\circ} \mathrm{C}$ and $90^{\circ} \mathrm{C}$. A few tests were also carried at near $30^{\circ} \mathrm{C}$. Nitrogen $\left(\mathrm{N}_{2}\right)$ was purged through the solution at a flow rate of $100 \mathrm{cc} / \mathrm{min}$ for 24 hours while the corrosion potential ( $E_{\text {corr }}$ ) was monitored. After the recording of $E_{c o r r}$, three polarization resistance (PR) tests (ASTM G 59) [23] followed by one cyclic polarization (CP) test (ASTM G 61) [23] were conducted. Nitrogen bubbling was carried throughout all the electrochemical tests. The electrochemical tests were carried out in a one-liter, three-electrode, borosilicate glass flask (ASTM G 5) [23]. A water-cooled condenser combined with a water trap was used to maintain solution concentration and controlled atmosphere. Solution temperatures were controlled by immersing the cell in a thermostatisized silicone oil bath. All the tests were carried at ambient pressure. The reference electrode was saturated silver chloride (SSC) electrode, which has a potential of $199 \mathrm{mV}$ more positive than the standard hydrogen electrode (SHE). The reference electrode was connected to the solution through a waterjacketed Luggin probe so that the electrode was maintained at near ambient temperature. The counter electrode was a flag $\left(36 \mathrm{~cm}^{2}\right)$ of platinum foil spot-welded to a platinum wire. All the potentials in this paper are reported in the SSC scale.

Most of the corrosion rates (CR) were obtained using the polarization resistance method (ASTM G 59) [23]. An initial potential of $20 \mathrm{mV}$ below the corrosion potential ( $E_{\text {corr }}$ ) was ramped to a final potential of $20 \mathrm{mV}$ above $E_{\text {corr }}$ at a rate of $0.167 \mathrm{mV} / \mathrm{s}$. Linear fits were constrained to the potential range of $10 \mathrm{mV}$ below $E_{\text {corr }}$ to $10 \mathrm{mV}$ above $E_{\text {corr }}$. The Tafel constants, $\beta_{\mathrm{a}}$ and $\beta_{\mathrm{c}}$, were assumed to be $\pm 0.12 \mathrm{~V} /$ decade. Corrosion rates were calculated using Equation 1

$$
C R(n m / y r)=k \frac{i_{\text {corr }}}{\rho} E W
$$


Where $\mathrm{k}$ is a conversion factor $\left(3.27 \times 10^{9} \mathrm{~nm} \cdot \mathrm{g} \cdot \mathrm{A}^{-1} \cdot \mathrm{cm}^{-1} \cdot \mathrm{yr}^{-1}\right), \mathrm{i}_{\mathrm{corr}}$ is the measured corrosion current density in $\mathrm{A} / \mathrm{cm}^{2}$, EW is the equivalent weight, and $\rho$ is the density of Alloy 22 $\left(8.69 \mathrm{~g} / \mathrm{cm}^{3}\right)$. Assuming an equivalent dissolution of the major alloying elements as $\mathrm{Ni}^{2+}$, $\mathrm{Cr}^{3+}, \mathrm{Mo}^{6+}, \mathrm{Fe}^{2+}$, and $\mathrm{W}^{6+}$, the EW for Alloy 22 is 23.28 (ASTM G 102) [23]. A few corrosion rates were obtained using the immersion tests (ASTM G 3) [23]. The coupons were approximately $25 \mathrm{~mm} \times 50 \mathrm{~mm} \times 3 \mathrm{~mm}$ thick. Tests were carried out for 96 hours and the test solution was changed every $24 \mathrm{~h}$. The immersion solutions were not deaerated. The immersion corrosion tests were performed at Haynes International in Kokomo, Indiana. Some of these data reported here has been published before [1].

Tests to assess the susceptibility of Alloy 22 to localized corrosion and passive stability were conducted using the cyclic potentiodynamic polarization technique (ASTM G 61) [23]. The potential scan was started approximately $100 \mathrm{mV}$ below $E_{\text {corr }}$ at a set scan rate of $0.167 \mathrm{mV} / \mathrm{s}$. The scan direction was usually reversed when the current density reached 5 $\mathrm{mA} / \mathrm{cm}^{2}$ in the forward scan. After the cyclic polarization tests the specimens were examined in an optical stereomicroscope at a magnification of 40 times to establish the mode of attack. A few specimens were also studied using a scanning electron microscope (SEM).

\section{RESULTS AND DISCUSSION}

\section{Corrosion Rates from Immersion (Weight Loss) Tests}

Table 1 shows the corrosion rates of four engineering $\mathrm{Ni}-\mathrm{Cr}-\mathrm{Mo}$ alloys in boiling aqueous solutions of acetic, formic and oxalic acids obtained using the immersion or weight loss method. Table 1 also shows the corrosion rate of two other engineering alloys (stainless steel and titanium) for comparative purposes. Table 1 shows that for each acid the lowest corrosion rates corresponded to Alloy 22. Figure 1 shows the corrosion rates for the alloys in boiling $10 \%$ oxalic acid. Even though the concentration of the used organic acid was different from each other, Table 1 illustrates that oxalic was the most aggressive acid towards the engineering alloys shown. For most alloys, the corrosion rate in $10 \%$ oxalic acid was between 10 to 100 times higher than the corrosion rate in either formic or acetic acid of higher concentration.

The corrosion rate by weight loss of all the alloys shown in Table 1 in a seawater type solution $\left(3.5 \% \mathrm{NaCl}\right.$ or $0.6 \mathrm{M} \mathrm{NaCl}$ ) at $90^{\circ} \mathrm{C}$ to boiling was below 0.1 mpy (below 2.5 $\mu \mathrm{m} /$ year). That is, all these alloys are highly resistant to general corrosion in near neutral saline solutions.

\section{The Corrosion Potential ( $\left.\mathrm{E}_{\text {corr }}\right)$}

Figure 2 shows the evolution of the corrosion potential $\left(E_{\text {corr }}\right)$ in time for Alloy 22 in $1 \mathrm{M} \mathrm{NaCl}$ and $0.1 \mathrm{M}$ oxalic acid at $30^{\circ} \mathrm{C}$. For both environments, $\mathrm{E}_{\text {corr }}$ decreased rapidly in the first two hours of testing and then remained more or less constant, or slightly decreased, as the time increased. Figure 2 shows that for the same temperature, $\mathrm{E}_{\mathrm{corr}}$ was approximately $200 \mathrm{mV}$ higher for the $0.1 \mathrm{M}$ oxalic acid solution than for the $1 \mathrm{M} \mathrm{NaCl}$ solution. That is, Alloy 22 seemed in a more active state in the salt solution. Table 2 and Figure 3 show $\mathrm{E}_{\text {corr }}$ 
for Alloy 22 in several aqueous solutions of oxalic acid and $\mathrm{NaCl}$ solutions as a function of the temperature. The value of $\mathrm{E}_{\text {corr }}$ in Fig. 3 was the value after $24 \mathrm{~h}$ immersion in the given solution (Table 2). In the tested temperature range, $\mathrm{E}_{\text {corr }}$ for Alloy 22 in oxalic acid was higher than in $\mathrm{NaCl}$ solutions. For the oxalic acid solutions, $\mathrm{E}_{\text {corr }}$ was somewhat higher the higher the concentration of the acid, especially at $60^{\circ} \mathrm{C}$ and $90^{\circ} \mathrm{C}$, probably due to slight oxidizing nature of this acid. For both solutions, as the temperature increased, $\mathrm{E}_{\text {corr }}$ decreased slightly.

Table 2 shows that $\mathrm{E}_{\mathrm{cor}}$ for Alloy 22 in $0.1 \mathrm{M}$ oxalic acid at near $30^{\circ} \mathrm{C}$ was approximately the same for the as welded (ASW) (JE0030-0031) and welded plus aged (WPA) (JE0013-0014) materials. That is, the precipitation of second phases such as mu and $\mathrm{P}$ in Alloy 22 did not seem to considerably modify the value of $\mathrm{E}_{\text {corr }}$. Table 2 also shows that the $E_{\text {corr }}$ of Alloy 22 in aerated oxalic acid solutions was higher than the $E_{\text {corr }}$ reported in Figure 3 for deaerated solutions. Moreover, as the time for aerated solutions increased from $24 \mathrm{~h}$ to $144 \mathrm{~h}, \mathrm{E}_{\text {corr }}$ increased (DEA3159-3160). The highest values of $\mathrm{E}_{\text {corr }}$ reported in Table 2 were $+49 \mathrm{mV}$ (SSC) and $+135 \mathrm{mV}$ (SSC) after $144 \mathrm{~h}$ of immersion in aerated $0.01 \mathrm{M}$ and $0.1 \mathrm{M}$ solutions at $60^{\circ} \mathrm{C}$, respectively. It has been reported before that the $\mathrm{E}_{\text {corr }}$ of Alloy 22 in aerated $0.1 \mathrm{M}$ oxalic acid at $30^{\circ} \mathrm{C}$ was $+124 \pm 8 \mathrm{mV}$ (SSC) after six months of testing [24].

\section{Corrosion Rates from Polarization Resistance (PR) Tests}

Table 2 and Figure 4 show the corrosion rates for Alloy 22 in $\mathrm{NaCl}$ and oxalic acid solutions as a function of temperature calculated using polarization resistance tests (see Experimental). These corrosion rates are not true corrosion rates and are given here for general reference only, that is, for example to compare the effect of temperature. These corrosion rates were calculated with assumed values of Tafel slopes. Figure 4 shows that the calculated corrosion rate of Alloy 22 in $1 \mathrm{M} \mathrm{NaCl}$ solution was approximately $0.4 \mu \mathrm{m} /$ year at $30^{\circ} \mathrm{C}$ and increased to approximately $2 \mu \mathrm{m} /$ year at $90^{\circ} \mathrm{C}$. The dependence between the corrosion rate and the temperature resulted on a low apparent Arrhenius activation energy of approximately $21 \mathrm{~kJ} / \mathrm{mol}$ (the correlation coefficient was rather poor at $\mathrm{R}^{2}=0.22$ ). The calculated values of corrosion rate of Alloy 22 in $\mathrm{NaCl}$ solutions (Fig. 4) were below the value of $0.1 \mathrm{mpy}(2.5 \mu \mathrm{m} / \mathrm{year})$ reported for the immersion tests. It has been previously published that that the corrosion rate of Alloy 22, measured through AC impedance, in aerated $1000 \mathrm{ppm} \mathrm{NaCl}$ solution at $95^{\circ} \mathrm{C}$ was approximately $0.3 \mu \mathrm{m} /$ year [25].

Figure 4 shows that the corrosion rate of Alloy 22 in oxalic acid solutions was higher than the corrosion rate in $\mathrm{NaCl}$ solution. For oxalic acid, at each acid concentration the corrosion rate increased with the temperature and at each temperature the corrosion rate increased with the acid concentration. The temperature dependence of the corrosion rate was higher for oxalic acid than for $\mathrm{NaCl}$ solutions. For oxalic acid, it resulted in a higher apparent activation energies of $98 \mathrm{~kJ} / \mathrm{mol}$ for $0.01 \mathrm{M}$ oxalic, $63 \mathrm{~kJ} / \mathrm{mol}$ for $0.1 \mathrm{M}$ oxalic and $78 \mathrm{~kJ} / \mathrm{mol}$ for $1 \mathrm{M}$ oxalic (The correlation coefficients for oxalic acid were better than for $\mathrm{NaCl}$. They were $\mathrm{R}^{2}=0.925,0.982$ and 0.998 for $0.01 \mathrm{M}, 0.1 \mathrm{M}$ and $1 \mathrm{M}$, respectively).

Figure 4 shows that the corrosion rate of Alloy 22 in $0.1 \mathrm{M}$ oxalic acid can increase from approximately $60 \mu \mathrm{m} /$ year $(\sim 2 \mathrm{mpy})$ at $30^{\circ} \mathrm{C}$ to approximately $2000 \mu \mathrm{m} /$ year $(\sim 80 \mathrm{mpy})$ at $90^{\circ} \mathrm{C}$. These values of corrosion rates were obtained in freshly ground samples after exposure to the corroding deaerated solution for only $24 \mathrm{~h}$. Table 1 and Figure 1 show that the corrosion rate of Alloy 22 in aerated boiling $10 \%$ oxalic acid ( $1 \mathrm{M})$ after $96 \mathrm{~h}$ of exposure was $6.27 \mathrm{mpy}(159 \mu \mathrm{m} / \mathrm{year})$. This is at least one order of magnitude lower than the 
corrosion rates in deaerated oxalic acid solutions obtained electrochemically through polarization resistance tests (Figure 4). The difference in the corrosion rate can be attributed to a decrease of the corrosion rate due to the exposure time and the presence of air (oxygen) in the case of the immersion test. Table 2 shows that the electrochemically measured (PR) corrosion rate of Alloy 22 after $24 \mathrm{~h}$ exposure in aerated $0.01 \mathrm{M}$ oxalic acid at $60^{\circ} \mathrm{C}$ was 2.55 $\mu \mathrm{m} /$ year and decreased four fold to $0.59 \mu \mathrm{m} /$ year after $144 \mathrm{~h}$ exposure. Similarly, in aerated $0.1 \mathrm{M}$ oxalic acid at $60^{\circ} \mathrm{C}$, the corrosion rate also decreased four fold in the same period of time (from $4.68 \mu \mathrm{m} /$ year to $1.14 \mu \mathrm{m} /$ year).

Table 2 shows that the corrosion rate of Alloy 22 in $0.1 \mathrm{M}$ oxalic acid at near $30^{\circ} \mathrm{C}$ of ASW material was $62 \pm 16 \mu \mathrm{m} /$ year and that of WPA material was $20 \pm 8 \mu \mathrm{m} / \mathrm{year}$. This was a surprising finding and an explanation for it cannot be offered at this time. In general, for near neutral solutions, the corrosion rate of thermally aged material does not change from the non-aged material [25]. In many acidic solutions, the corrosion rate of aged material is higher than the corrosion rate of non-aged material [25].

Figure 5 shows the average corrosion rates (calculated from the data in Table 2) for Alloy 22 at $60^{\circ} \mathrm{C}$ and $90^{\circ} \mathrm{C}$ plotted as a function of the oxalic acid concentration. At each temperature, the corrosion rate approximately decreased by one half when the concentration is dropped by one tenth. If this relationship between corrosion rate and acid concentration is valid at other acid concentrations, it may allow the prediction of the corrosion rate at more dilute acid concentrations (e.g. $10^{-4} \mathrm{M}$ oxalic acid).

\section{Potentiodynamic Cyclic Polarization}

Figure 6 shows the cyclic polarization of Alloy 22 MA MCA specimens in deaerated $1 \mathrm{M} \mathrm{NaCl}$ solution at $30^{\circ} \mathrm{C}, 60^{\circ} \mathrm{C}$ and $90^{\circ} \mathrm{C}$. The three polarization curves show an anodic peak at approximately -0.1 to $-0.2 \mathrm{~V}$ (SSC). The potential at which the peaks occurred seemed to decrease slightly as the temperature increased. The origin of these peaks is still unknown, but could be result of transformations in the oxidation state of species contained in the oxide film. At $30^{\circ} \mathrm{C}$ and $60^{\circ} \mathrm{C}$, the breakdown potential was approximately $+0.6 \mathrm{~V}$ (SSC) and the reverse scan of the polarization curve did not show a hysteresis. Examination of the tested specimens showed that they were free from localized corrosion. At $90^{\circ} \mathrm{C}$, the breakdown potential was slightly lower $(\sim+0.3 \mathrm{~V})$ and the reverse scan showed a delayed hysteresis suggesting the presence of crevice corrosion. Examination of the tested specimens showed the presence of noticeable crevice corrosion under the ceramic-PTFE crevice formers. Figure 7 shows a low magnification view of the specimen at the location of one of the teeth of the crevicing washer. Crevice corrosion occurred below and around the entire perimeter of this tooth and of almost all of the 24 teeth of the washer. The creviced area and its surroundings had large amount of deposits or corrosion products. EDS analysis showed that these deposits contained oxygen and up to $40 \%$ (in weight) of Mo and $11 \%$ of W. The presence of Mo and W oxides inside creviced corroded areas of Ni-Cr-Mo alloys was reported before [26]. Figure 8 shows a detail of the corrosion appearance in the creviced area. A typical crystallographic type etching or dissolution occurred. This type of corrosion pattern is generally obtained in Alloy 22 when it is corroded in hot solutions of hydrochloric acid $(\mathrm{HCl})[22]$.

The polarization curves of Alloy 22 in deaerated $1.25 \mathrm{M} \mathrm{NaCl}$ solution were similar to those in $1 \mathrm{M} \mathrm{NaCl}$. A similar corrosion pattern was also obtained after the tests. In the 1.25 
$\mathrm{M} \mathrm{NaCl}$ solution at $60^{\circ} \mathrm{C}$ there was a hint of localized attack, a shallow dull attack that was negligible compared to the appearance of the specimen tested in the same solution at $90^{\circ} \mathrm{C}$. Table 3 outlines the mode of corrosion in the samples after the cyclic polarization in the specimens.

Figure 9 shows the cyclic polarization curve for Alloy $22 \mathrm{MA} \mathrm{MCA}$ in deaerated 0.01 $\mathrm{M}$ oxalic acid at $30^{\circ} \mathrm{C}, 60^{\circ} \mathrm{C}$ and $90^{\circ} \mathrm{C}$. The current density in the passive region of potentials increased approximately one order of magnitude as the temperature increased from $30^{\circ} \mathrm{C}$ to $60^{\circ} \mathrm{C}$ to $90^{\circ} \mathrm{C}$. Figure 4 shows a similar increase for the corrosion rate as the temperature increased. Figure 9 shows that the polarization curves exhibited an anodic peak at approximately $+0.05 \mathrm{~V}(\mathrm{SSC})$. This peak was more noticeable at $30^{\circ} \mathrm{C}$, it was reduced at $60^{\circ} \mathrm{C}$ and completely disappeared at $90^{\circ} \mathrm{C}$. The origin of this anodic peak is still not understood. The breakdown potential was similar for the three temperatures and approximately $+0.8 \mathrm{~V}$ (SSC). This potential probably corresponded to the potential of oxygen evolution. None of the cyclic polarization curves showed hysteresis during the reverse scan and none of the tested specimens exhibited localized corrosion in oxalic acid solutions (Table 3). At $60^{\circ} \mathrm{C}$ and $90^{\circ} \mathrm{C}$ the samples suffered grain boundary etching typical of oxalic acid on $\mathrm{Ni}-\mathrm{Cr}-\mathrm{Mo}$ alloys (Figure 10). For metallographic studies, $\mathrm{Ni}-\mathrm{Cr}-\mathrm{Mo}$ alloys are commonly etched in a solution containing oxalic acid.

Figure 11 shows the cyclic polarization curves of Alloy $22 \mathrm{MA} \mathrm{MCA}$ in $0.01 \mathrm{M}, 0.1$ $\mathrm{M}$ and $1 \mathrm{M}$ oxalic acid at $60^{\circ} \mathrm{C}$. Figure 11 shows that the current density in the passive region of potentials increased as the acid concentration increased. Similarly to Figure 9, there was an anodic peak at approximately $+0.05 \mathrm{~V}$ (SSC) that became smaller as the acid concentration increased, probably overshadowed by the higher current density in the passive region of potentials. Figure 12 shows the cyclic polarization curves for ASW and WPA Alloy 22 in $0.1 \mathrm{M}$ oxalic acid at $33^{\circ} \mathrm{C}$. There were no major differences between both curves. Just above the corrosion potential, the current density for the WPA specimen was lower than the current density for the ASW specimen. This agrees with the lower corrosion rate for the WPA material reported before. After the tests, the specimens showed preferential etching of the weld seam. In the WPA samples, the base metal also showed grain boundary etching.

\section{Parameters from the Cyclic Polarization Curves}

In the polarization curves (e.g. Figure 6) there are several typical potentials. One typical potential is the breakdown potential for which the current density increases significantly and rapidly above the "passive" current density. That is, in the forward scan, when the current density reaches $200 \mu \mathrm{A} . \mathrm{cm}^{2}$ the alloy could be considered depassivated. Similarly, when the current density in the reverse scan has reached between $10 \mu \mathrm{A} / \mathrm{cm}^{2}$ and 1 $\mu \mathrm{A} / \mathrm{cm}^{2}$, the alloy would have regained its passive behavior prior to the breakdown. Hence, parameters can be extracted from the cyclic polarization curves that indicate the potentials at which the forward current density reached $200 \mu \mathrm{A} / \mathrm{cm}^{2}$ (E200) and the reverse current density reached $10 \mu \mathrm{A} / \mathrm{cm}^{2}$ (ER10). These values of characteristic potentials are listed in Table 2. These parameters allow comparison among polarization curves without the clutter of

\footnotetext{
${ }^{1}$ The region of potentials between the corrosion potential and the breakdown potential is generally called the passive region of potentials. However, in certain tests carried out in aggressive environments such as in hot 0.1 $\mathrm{M}$ and $1 \mathrm{M}$ oxalic acid solutions, the value of current density at this region of potentials was too high to be called passive current density.
} 
superimposing too many curves. These two parameters (E200 and ER10) could capture the basic shape of the potentiodynamic curves. The technique of selecting values of potential for fixed values of current densities has been used by other investigators [5,13].

Figure 13 shows the values of $\mathrm{E}_{\mathrm{corr}}$ and $\mathrm{E} 200$ (from Table 2) for $\mathrm{NaCl}$ solutions and $0.1 \mathrm{M}$ oxalic acid. Both $\mathrm{E}_{\mathrm{corr}}$ and $\mathrm{E} 200$ for oxalic acid were slightly higher than for $\mathrm{NaCl}$ solutions. Similarly as shown before for $E_{\text {corr }}$ (Fig. 3), E200 decreased as the temperature increased. The gap (difference) between $\mathrm{E}_{\text {corr }}$ and E200 indicates the range of potential that the alloy needs to overcome before a fast dissolution rate is achieved. That is, this potential difference represents a certain margin of safety against catastrophic fast corrosion (localized attack or transpassive dissolution). In the present case, catastrophic dissolution is not expected since even at $90^{\circ} \mathrm{C}$ the gap between $E_{\text {corr }}$ and $E 200$ was more than $800 \mathrm{mV}$ for both solutions. Figure 14 shows the values of $\mathrm{E}_{\text {corr }}$ and $\mathrm{ER} 10$ (from Table 2) for $\mathrm{NaCl}$ solutions. ER10 represents a form of repassivation potential. Even though the values of ER10 decreased faster as the temperature increased (compared to E200 in Fig. 13), the gap between $E_{\text {corr }}$ and ER10 was still higher than $400 \mathrm{mV}$ at $90^{\circ} \mathrm{C}$. That is, if localized corrosion could be initiated in $1 \mathrm{M} \mathrm{NaCl}$ solution at $90^{\circ} \mathrm{C}$ at high applied potentials $(>+0.6 \mathrm{~V}$ in Fig. 6), this crevice corrosion could not be sustained at potentials below approximately $0 \mathrm{~V}$ (Figs 6 and 14). This needs to be verified further, for example, using constant potential tests.

\section{Concluding Remarks}

The anodic behavior of Alloy 22 has been presented in two independent solutions. One solution $(\mathrm{NaCl})$ offers low corrosion rates at the corrosion potential but may induce crevice corrosion in Alloy 22 at $90^{\circ} \mathrm{C}$ if the alloy is polarized anodically several hundreds of millivolts above the corrosion potential. The other solution (oxalic acid) does not promote localized corrosion; however, it may induce relatively high corrosion rates. It was estimated (Fig. 5) that the corrosion rate of Alloy 22 at $60^{\circ} \mathrm{C}$ would be in the order of $30 \mu \mathrm{m} /$ year even at an oxalic acid concentration of $10^{-4} \mathrm{M}$. This corrosion rate would be 30 times higher than the corrosion rate in $1 \mathrm{M} \mathrm{NaCl}$ at the same temperature (Fig. 4). Finally, there is still a need to investigate the effect that these two solutions would have on the corrosion behavior of Alloy 22 when they are combined in the same environment.

\section{CONCLUSION}

(1) Oxalic acid is one of the most aggressive organic acids towards Ni-Cr-Mo alloys such as Alloy 22.

(2) The corrosion rate of Alloy 22 in $0.1 \mathrm{M}$ oxalic acid at $60^{\circ} \mathrm{C}$ was measured to be as high as $200 \mu \mathrm{m} /$ year. The presence of air and longer immersion times decreased this value significantly. Thermal aging of Alloy 22 did not decrease its resistance to corrosion in oxalic acid.

(3) The general corrosion rate of Alloy 22 in oxalic acid solutions increased rapidly as the temperature and acid concentration increased. 
(4) Alloy 22 was not susceptible to localized corrosion in oxalic acid solutions.

(5) The general corrosion rate of Alloy 22 in $1 \mathrm{M} \mathrm{NaCl}$ solution at $60^{\circ} \mathrm{C}$ was below 1 $\mu \mathrm{m} / \mathrm{year}$.

(6) Alloy 22 was susceptible to crevice corrosion when it was anodically polarized in 1 $\mathrm{M} \mathrm{NaCl}$ at $90^{\circ} \mathrm{C}$. In the same solution, Alloy 22 was free from crevice corrosion at $60^{\circ} \mathrm{C}$.

\section{ACKNOWLEDGMENTS}

This work was performed under the auspices of the U. S. Department of Energy by the University of California Lawrence Livermore National Laboratory under contract $\mathrm{N}^{\circ} \mathrm{W}$ 7405-Eng-48. The work was supported by the Yucca Mountain Project, which is part of the DOE Office of Civilian Radioactive Waste Management (OCRWM).

\section{REFERENCES}

1. R. B. Rebak in Corrosion and Environmental Degradation, Volume II, p. 69, Wiley$\mathrm{VCH}$, Weinheim, Germany (2000).

2. R. B. Rebak and P. Crook, Advanced Materials and Processes, February 2000.

3. Yucca Mountain Science and Engineering Report, U. S. Department of Energy, Office of Civilian Radioactive Waste Management, DOE/RW-0539, Las Vegas, NV, May 2001.

4. G. M. Gordon, Corrosion, 58, 811 (2002).

5. B. A. Kehler, G. O. Dlevbare and J. R. Scully, Corrosion, 1042 (2001).

6. K. J. Evans and R. B. Rebak in Corrosion Science - A Retrospective and Current Status in Honor of Robert P. Frankenthal, PV 2002-13, p. 344-354 (The Electrochemical Society, 2002: Pennington, NJ).

7. G. O. Ilevbare, PVP-Vol. 449, Transportation, Storage and Disposal of Radioactive Materials - 2002, p. 55 (ASME, 2002: New York, NY).

8. S. D. Day, K. J. Evans and G. O. Ilevbare, paper presented at the $202^{\text {nd }}$ Electrochemical Society Meeting, Salt Lake City, UT, 20-24 October 2002 (to be published by The Electrochemical Society, 2003: Pennington, NJ).

9. L. L. Wong, D. V. Fix, J. C. Estill, R. D. McCright and R. B. Rebak, Presented at the Fall Meeting of the Materials Research Society, Boston, MA 2-5 December 2002 (to be published by MRS, 2003: Warrendale, PA).

10. P. D. Hailey and G. E. Gdowski, Presented at the Fall Meeting of the Materials Research Society, Boston, MA 2-5 December 2002 (to be published by MRS, 2003: Warrendale, PA).

11. O. Pensado, D. S. Dunn and G. A. Cragnolino, Presented at the Fall Meeting of the Materials Research Society, Boston, MA 2-5 December 2002 (to be published by MRS, 2003: Warrendale, PA). 
12. N. S. Meck, P. Crook, S. D. Day and R. B. Rebak, Corrosion/03, Paper 03682 (NACE International, 2003: Houston, TX).

13. D. S. Dunn, L. Yang, Y. - M. Pan and G. A. Cragnolino, Corrosion/03, Paper 03697 (NACE International, 2003: Houston, TX).

14. A. I. Pulvirenti, K. M. Needham, M. A. Adel-Hadadi, E. J. Bishop, A. Barkatt, C. R. Marks and J. A. Gorman, Corrosion/03, Paper 03693 (NACE International, 2003: Houston, TX).

15. CRC Handbook of Chemistry and Physics, $70^{\text {th }}$ Edition, p. D-163 and B-81 (CRC Press, 1990: Boca Raton, FL).

16. R. J. Palmer Jr., J. Siebert and P. Hirsch, Microbial Ecology, 21, 253 (1991).

17. P. Hirsch, F. E. W Eckhardt and R. J. Palmer Jr., Can. J. Botany, 73, 1384 (1995).

18. J. M. Schrickx, M. J. H. Raedts, A. H. Stouthamer and H. W. van Verseveld, Analytical Biochem., 231, 175 (1995)

19. C. Sans, J. Mata-Alvarez, F. Cecchi, P. Pavan and A. Bassetti, Bioresource Technol., 51,89 (1995).

20. D. A. Rockert, C. E. Glatz and B. A. Glatz, Enzyme and Microbial Technol., 22, 409 (1998).

21. J. Yu, J. Biotechnology, 86, 105 (2001).

22. R. B. Rebak, T. S. E. Summers and R. M. Carranza, in Scientific Basis for Nuclear Waste Management XXIII, Vol. 608, p. 109 (Materials Research Society, 2000: Warrendale, PA).

23. American Society for Testing and Materials, Standard G-15, Volume 3.02 (ASTM, 2001: West Conshohocken, PA).

24. J. C. Estill, G. A. Hust and R. B. Rebak, paper 03688, Corrosion/03 (NACE International, 2003: Houston, TX).

25. R. B. Rebak, T. S. E. Summers, T. Lian, R. M Carranza, J. R. Dillman, T. Corbin and P. Crook, paper 02542, Corrosion/02 (NACE International, 2002: Houston, TX).

26. R. B. Rebak, N. E. Koon, J. P. Cotner and P. Crook, in Passivity and Localized Corrosion, PV 99-27, p. 473 (The Electrochemical Society, 1999: Pennington, NJ). 
Table 1

Corrosion Rates of Engineering Alloys in Boiling Solutions of Organic Acids Immersion tests (ASTM G 3). Data From Ref [1] and: Haynes International Inc.

\begin{tabular}{|c|c|c|c|c|c|c|c|}
\hline \multirow[t]{2}{*}{ Acid } & Concentration & \multicolumn{6}{|c|}{ Corrosion Rates in mpy $(\mu \mathrm{m} / \mathrm{ye}$ )ar $)$} \\
\hline & & $\begin{array}{l}316 \mathrm{~L} \mathrm{SS} \\
\text { (S31603) }\end{array}$ & $\begin{array}{c}\text { Ti Gr } 7 \\
(\mathrm{R} 52400)\end{array}$ & $\begin{array}{c}\mathrm{C}-276 \\
(\mathrm{~N} 10276) \\
\end{array}$ & $\begin{array}{l}\text { Alloy } 22 \\
(\mathrm{~N} 06022)\end{array}$ & $\begin{array}{l}\text { Alloy } 625 \\
(\text { N06625) } \\
\end{array}$ & $\begin{array}{l}\text { Alloy C-4 } \\
\text { (N06455) }\end{array}$ \\
\hline $\begin{array}{c}\text { Acetic, } \\
\mathrm{CH}_{3} \mathrm{COOH}\end{array}$ & $99 \%(-16 \mathrm{M})$ & $7.4(188)$ & $0.2(5.08)$ & $\begin{array}{c}0.21 \\
(5.33)\end{array}$ & $\begin{array}{c}0.10 \\
(2.54)\end{array}$ & $\begin{array}{c}0.18 \\
(4.57)\end{array}$ & $\begin{array}{c}0.12 \\
(3.05)\end{array}$ \\
\hline $\begin{array}{c}\text { Formic } \\
\mathrm{H}_{2} \mathrm{COOH} \\
\end{array}$ & $50 \%(\sim 10 \mathrm{M})$ & $27.8(706)$ & $0.5(12.7)$ & $0.7(18.8)$ & $\begin{array}{r}1.40 \\
(35.6)\end{array}$ & $\begin{array}{r}2.57 \\
(65.3) \\
\end{array}$ & $\begin{array}{c}1.53 \\
(38.9)\end{array}$ \\
\hline $\begin{array}{c}\text { Oxalic } \\
\mathrm{COOHCOOH} \\
\end{array}$ & $10 \%(\sim 1 \mathrm{M})$ & $\begin{array}{c}77.9 \\
(1,979) \\
\end{array}$ & $\begin{array}{c}106 \\
(2,692) \\
\end{array}$ & $8.13(207)$ & $6.27(159)$ & $12.9(328)$ & $7.00(178)$ \\
\hline & & & & & & & \\
\hline
\end{tabular}

(A) Corrosion rates for $\mathrm{S} 31600$

Table 2: Experimental Conditions and Results

\begin{tabular}{|c|c|c|c|c|c|c|}
\hline Specimen ID & $\begin{array}{l}\text { Type of } \\
\text { Material }\end{array}$ & $\begin{array}{c}\text { Electrolyte, Temperature } \\
\left({ }^{\circ} \mathrm{C}\right)\end{array}$ & $\begin{array}{l}24 \mathrm{~h} \mathrm{E}_{\text {corr }} \\
(\mathrm{mV}, \mathrm{SSC})\end{array}$ & $\begin{array}{l}\text { Corrosion Rates from } \\
\text { PR ( } \mu \mathrm{m} / \text { year })\end{array}$ & $\begin{array}{l}\mathrm{E} 200 \\
(\mathrm{mV}, \\
\mathrm{SSC})\end{array}$ & $\begin{array}{l}\text { ER10 } \\
(\mathrm{mV}, \\
\text { SSC) }\end{array}$ \\
\hline RBRCl1a & MA Prism & $0.01 \mathrm{M} \mathrm{NaCl}, 60$ & -492 & $0.425,0.430,0.396$ & 889 & 589 \\
\hline RBRC11b & MA Prism & $0.01 \mathrm{M} \mathrm{NaCl}, 60$ & -454 & $0.366,0.416,0.485$ & 888 & 576 \\
\hline DEA3255 & MA MCA & $1 \mathrm{M} \mathrm{NaCl}, 30$ & -349 & $0.321,0.235,0.253$ & 865 & 676 \\
\hline DEA3256 & MA MCA & $1 \mathrm{M} \mathrm{NaCl}, 30$ & -479 & $1.606,1.511,1.554$ & 847 & 713 \\
\hline DEA3257 & MA MCA & $1 \mathrm{M} \mathrm{NaCl}, 30$ & -461 & $0.786,0.423,0.297$ & 843 & 674 \\
\hline DEA3141 & MA MCA & $1 \mathrm{M} \mathrm{NaCl}, 60$ & -355 & $1.24,1.28,1.56$ & 853 & 513 \\
\hline DEA3142 & MA MCA & $1 \mathrm{M} \mathrm{NaCl}, 60$ & -390 & $2.52,1.60,1.47$ & 843 & 493 \\
\hline DEA3264 & MA MCA & $1 \mathrm{M} \mathrm{NaCl}, 60$ & -429 & $0.27,0.33,0.31$ & 856 & 700 \\
\hline DEA3265 & MA MCA & $1 \mathrm{M} \mathrm{NaCl}, 60$ & -520 & $1.55,1.17,1.27$ & 846 & 695 \\
\hline DEA1321 & MA Wire & $1 \mathrm{M} \mathrm{NaCl}, 60$ & -523 & $0.506,0.525,1.58$ & 753 & 639 \\
\hline DEA1326 & MA Wire & $1 \mathrm{M} \mathrm{NaCl}, 60$ & -257 & $0.568,0.260,0.884$ & 760 & 652 \\
\hline DEA1297 & MA Wire & $1 \mathrm{M} \mathrm{NaCl}, 60$ & $-430(1 \mathrm{~h})$ & $2.501,2.235,2.004$ & 750 & 413 \\
\hline RBRC10a & MA Prism & $1 \mathrm{M} \mathrm{NaCl}, 60$ & -449 & $0.163,0.119,0.243$ & 784 & 588 \\
\hline RBRC10b & MA Prism & $1 \mathrm{M} \mathrm{NaCl}, 60$ & -445 & $0.377,0.573,0.379$ & 792 & 593 \\
\hline RBRC10c & MA Prism & $1 \mathrm{M} \mathrm{NaCl}, 60$ & -447 & $0.875,0.832,0.457$ & 798 & 590 \\
\hline DEA3267 & MA MCA & $1.25 \mathrm{M} \mathrm{NaCl}, 60$ & -369 & $0.14,0.15,0.17$ & 871 & 696 \\
\hline DEA3268 & $\mathrm{MA} \mathrm{MCA}$ & $1.25 \mathrm{M} \mathrm{NaCl}, 60$ & -421 & $0.52,0.58,0.67$ & 871 & 695 \\
\hline DEA3147 & MA MCA & $1.25 \mathrm{M} \mathrm{NaCl}, 60$ & -428 & $0.77,0.70,0.58$ & 868 & 712 \\
\hline DEA3148 & MA MCA & $1.25 \mathrm{M} \mathrm{NaCl}, 60$ & -426 & $0.75,0.87,0.83$ & 864 & 713 \\
\hline DEA3273 & $\mathrm{MA} \mathrm{MCA}$ & $1.25 \mathrm{M} \mathrm{NaCl}, 60$ & -458 & $0.13,0.05,0.15$ & 866 & 709 \\
\hline DEA3143 & MA MCA & $1 \mathrm{M} \mathrm{NaCl}, 90$ & -405 & $3.48,4.45,2.25$ & 740 & 64 \\
\hline DEA3144 & MA MCA & $1 \mathrm{M} \mathrm{NaCl}, 90$ & -446 & $3.38,3.84,11.63$ & 722 & 46 \\
\hline KK006 & ASW, Prism & $1 \mathrm{M} \mathrm{NaCl}, 90$ & -404 & $0.16,0.21$ & 716 & 570 \\
\hline DEA3262 & MA MCA & $1 \mathrm{M} \mathrm{NaCl}, 90$ & -571 & $1.93,1.66,1.36$ & 709 & 96 \\
\hline DEA3263 & $\mathrm{MA} M C A$ & $1 \mathrm{M} \mathrm{NaCl}, 90$ & -594 & $2.55,2.40,1.29$ & 703 & 81 \\
\hline
\end{tabular}




\begin{tabular}{|c|c|c|c|c|c|c|}
\hline DEA1322 & MA Wire & $1 \mathrm{M} \mathrm{NaCl}, 90$ & -590 & $2.762,4.625,4.941$ & 644 & 370 \\
\hline \begin{tabular}{|l} 
DEA1298 \\
\end{tabular} & MA Wire & $1 \mathrm{M} \mathrm{NaCl}, 90$ & $-499(1 \mathrm{~h})$ & $1.789,1.553,1.279$ & 648 & 309 \\
\hline DEA3145 & $\mathrm{MA} \mathrm{MCA}$ & $1.25 \mathrm{M} \mathrm{NaCl}, 90$ & -350 & $34.78,33.27,33.36$ & 766 & 810 \\
\hline DEA3146 & $\mathrm{MA} \mathrm{MCA}$ & $1.25 \mathrm{M} \mathrm{NaCl}, 90$ & -437 & $3.70,2.83,3.91$ & 712 & $\sim 90$ \\
\hline DEA3269 & $\mathrm{MA} \mathrm{MCA}$ & $1.25 \mathrm{M} \mathrm{NaCl}, 90$ & -548 & $1.21,1.04,0.61$ & 722 & 31 \\
\hline DEA3271 & $\mathrm{MA} M \mathrm{MCA}$ & $1.25 \mathrm{M} \mathrm{NaCl}, 90$ & -457 & $0.41,0.51,0.23$ & 649 & 70 \\
\hline DEA3244 & MA MCA & 0.01 M Oxalic, 30 & -295 & $4.438,5.270$ & 921 & 850 \\
\hline$\overline{D E A 3245}$ & MA MCA & $0.01 \mathrm{M}$ Oxalic, 30 & -214 & $0.747,0.555,0.501$ & 895 & 823 \\
\hline$D F A 2246$ & & $0018 \Omega$ & & & & \\
\hline DEA3246 & MA MCA & $0.01 \mathrm{M}$ Oxalic, 60 & -294 & $146.6,142.2,141.9$ & 866 & $\mathrm{NA}$ \\
\hline DEA3247 & MA MCA & $0.01 \mathrm{M}$ Oxalic, 60 & -290 & $94.62,95.63,95.79$ & 881 & NA \\
\hline$\overline{D E A} 3160$ & MA MCA & $0.01 \mathrm{M}$ Oxalic, $60^{\AA}$ & $24 \mathrm{~h}=-30$ & $2.60,2.62,2.43$ & $\mathrm{NA}$ & $\widehat{N A}$ \\
\hline$\overline{\text { DEA3160 }}$ & MA MCA & $0.01 \mathrm{M}$ Oxalic, $60^{\mathrm{A}}$ & $144 h=49$ & $0.60,0.58,0.60$ & 862 & 800 \\
\hline DEA3253 & MA MCA & 0.01 M Oxalic, 90 & -315 & 922.9 .894 .2 .8513 & 900 & NA \\
\hline DEA3254 & MA MCA. & $0.01 \mathrm{M}$ Oxalic, 90 & -313 & $814.5,804.5,811.8$ & 916 & $\mathrm{NA}$ \\
\hline$\widehat{\text { DEA3157 }}$ & MA MCA & $0.1 \mathrm{M}$ Oxalic 30 & -289 & 547254715479 & 926 & 876 \\
\hline$\overline{D E A 3158}$ & $\mathrm{MA} \mathrm{MCA}$ & $0.1 \mathrm{M}$ Oxalic, 30 & -269 & $55.38,53.25,54.18$ & 936 & 884 \\
\hline DEA1303 & MA Wire & 0.1 M Oxalic, 30 & $-127(1 \mathrm{~h})$ & $4.971,1.591,5.276$ & 923 & 808 \\
\hline DEA1304 & MA wire & $0.1 \mathrm{M}$ Oxalic, 30 & $-144(1 \mathrm{~h})$ & $3.109,1.572,3.356$ & 905 & 792 \\
\hline JE0030 & ASW MCA & $0.1 \mathrm{M}$ Oxalic, 33 & -250 & $47.89,44.94,46.59$ & 954 & 910 \\
\hline JE0031 & ASW MCA & 0.1 M Oxalic, 33 & -269 & $78.70,74.28,79.83$ & 936 & 890 \\
\hline JE0013 & WPA MCA & $0.1 \mathrm{M}$ Oxalic, 31 & -247 & $14.42,12.05,10.25$ & 942 & 882 \\
\hline JE0014 & WPA MCA & $0.1 \mathrm{M}$ Oxalic, 34 & -258 & $28.75,26.96,27.56$ & 958 & 902 \\
\hline DEA3161 & MA MCA & 0.1 M Oxalic, 60 & -254 & $327.8,337.5,341.4$ & 888 & $\overline{\mathrm{NA}}$ \\
\hline$\overline{D E A 3162}$ & MA MCA & $0.1 \mathrm{M}$ Oxalic, 60 & -256 & $344.8,335.4,344.1$ & 892 & -59 \\
\hline DEA3159 & MA MCA & $0.1 \mathrm{M}$ Oxalic $60^{\mathrm{A}}$ & $24 \mathrm{~h}=-43$ & $4.33,4.90,4.82$ & NA & $\mathrm{NA}$ \\
\hline DEA3159 & MA MCA & $0.1 \mathrm{M}$ Oxalic, $60^{\mathrm{A}}$ & $144 h=135$ & $1.15,1.13,1.15$ & 925 & 873 \\
\hline$\overline{\text { DEA3169 }}$ & MA MCA & $0.1 \mathrm{M}$ Oxalic, 90 & -303 & $3321,3249,3423$ & NA & $\overline{\mathrm{NA}}$ \\
\hline DEA3170 & MA MCA & $0.1 \mathrm{M}$ Oxalic, 90 & -317 & $3759,3752,3731$ & NA & $\mathrm{NA}$ \\
\hline DEA3163 & MA MCA & 1 M Oxalic, 60 & -210 & $571.8,575.9,583.1$ & 904 & -145 \\
\hline$\overline{\text { DEA3164 }}$ & $\longdiv { \mathrm { MA } \mathrm { MCA } }$ & $1 \mathrm{M}$ Oxalic, 60 & -197 & $525.2,530.7,536.0$ & 951 & -121 \\
\hline$\overline{\text { DEA3165 }}$ & MA MCA & $1 \mathrm{M}$ Oxalic, 90 & -263 & 5037,5478 & $\mathrm{NA}$ & $\mathrm{NA}$ \\
\hline$\longdiv { \text { DEA3166 } }$ & MA MCA & $1 \mathrm{M}$ Oxalic, 90 & -261 & $6118,5890,5944$ & $\mathrm{NA}$ & NA \\
\hline$\widehat{\text { RBRC12a }}$ & MA Prism & M Acetic 60 & -104 & 0.59706770382 & 849 & 784 \\
\hline RBRC13b & MA Prism & $1 \mathrm{M}$ Acetic, 60 & -178 & $0.660,0.202,0.366$ & 845 & 784 \\
\hline
\end{tabular}

$\mathrm{A}=$ In air, $\mathrm{MA}=$ mill annealed, $\mathrm{NA}=$ Not available (the value of potentials are not available because the test was terminated or because the current densities were outside the given margin), ASW $=$ As-Welded, WPA $=$ Welded plus Aged (at $700^{\circ} \mathrm{C}$ for $173 \mathrm{~h}$ ). $E_{\text {corr }}=$ It is the free corroding potential after $24 \mathrm{~h}$ exposure in the given electrolyte (other times when noted). E200 = It is the potential in the forward scan of a cyclic polarization curve where the current density reaches $200 \mu \mathrm{A} / \mathrm{cm}^{2}$. ER $10=$ It is the potential in the reverse polarization where the current density first reaches $10 \mu \mathrm{A} / \mathrm{cm}^{2}$. 
Table 3

Mode of Attack in the Specimens after Anodic Polarization

\begin{tabular}{|c|c|c|}
\hline Solution & $\begin{array}{c}\text { Temperature } \\
\left({ }^{\circ} \mathrm{C}\right)\end{array}$ & Mode of Attack After Cyclic Polarization \\
\hline $\begin{array}{c}1 \mathrm{M}-1.25 \mathrm{M} \\
\mathrm{NaCl}\end{array}$ & $30-60$ & $\begin{array}{l}\text { Samples golden iridescent or bluish. No localized corrosion. General } \\
\text { transpassive dissolution outside the crevice former area }\end{array}$ \\
\hline $\begin{array}{c}1 \mathrm{M}-1.25 \mathrm{M} \\
\mathrm{NaCl}\end{array}$ & 90 & $\begin{array}{l}\text { Samples yellow-light brown with shades of iridescent blue. } \\
\text { Noticeable localized crevice corrosion around the entire perimeter of } \\
\text { the crevice formers. Transpassive dissolution in the part of the } \\
\text { specimen exposed to the bulk solution. }\end{array}$ \\
\hline $\begin{array}{c}\text { 0.01-0.1 M } \\
\text { Oxalic Acid }\end{array}$ & 30 & $\begin{array}{l}\text { Little or no attack. Transpassive dissolution outside crevice formers. } \\
\text { No Localized corrosion. }\end{array}$ \\
\hline $\begin{array}{c}\text { O.01-0.1 M } \\
\text { Oxalic Acid }\end{array}$ & $60-90$ & $\begin{array}{l}\text { Grain boundary etching. Major dissolution outside the crevice } \\
\text { formers. No localized corrosion }\end{array}$ \\
\hline $\begin{array}{c}\text { 1 M Oxalic } \\
\text { Acid }\end{array}$ & $60-90$ & $\begin{array}{l}\text { General dissolution. No grain boundary etching, no localized } \\
\text { corrosion }\end{array}$ \\
\hline
\end{tabular}




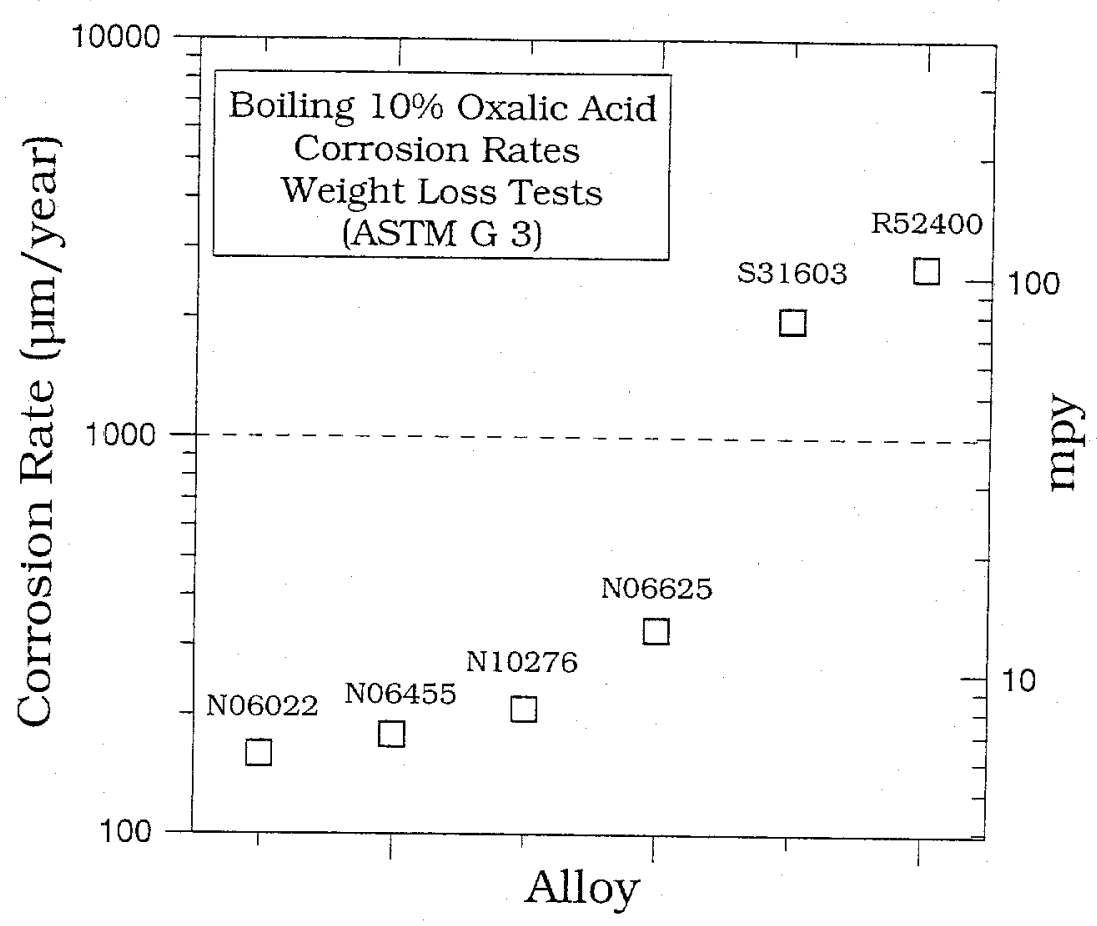

Figure 1: Corrosion Rates of Engineering Alloys in Boiling 10\% Oxalic Acid. Data from Ref. 1 and from Haynes International.

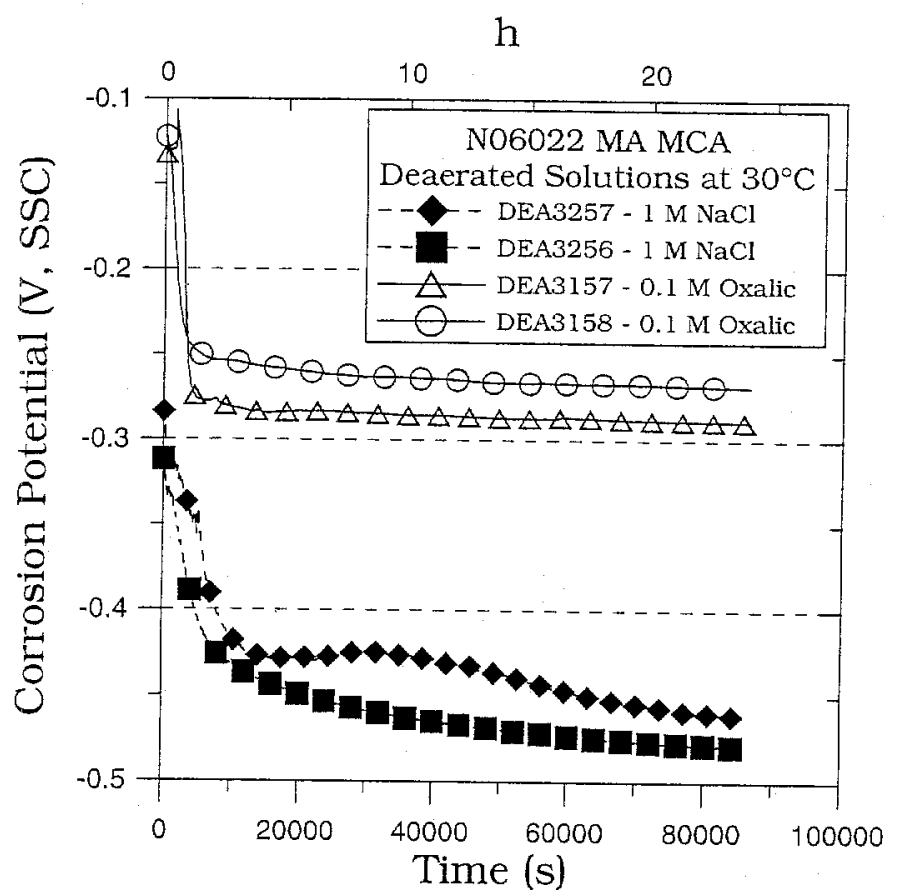

Figure 2: Evolution of Ecorr for Alloy 22 as a function of time 


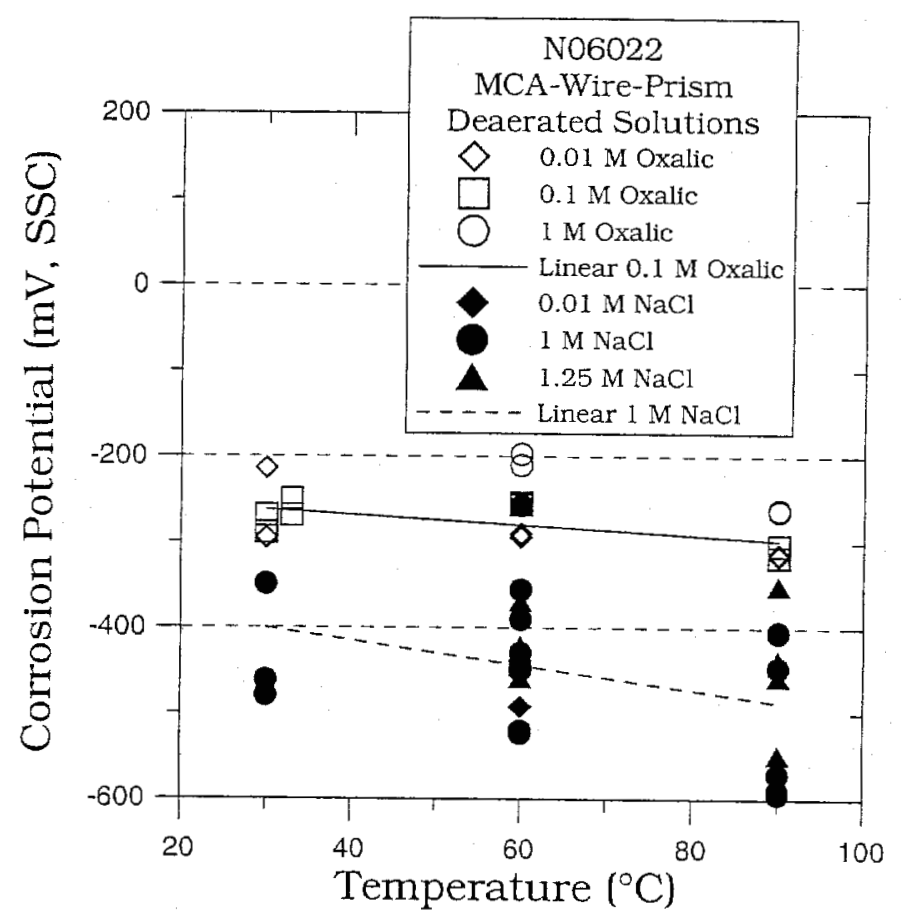

Figure 3: Ecorr of Alloy 22 as a function of the temperature

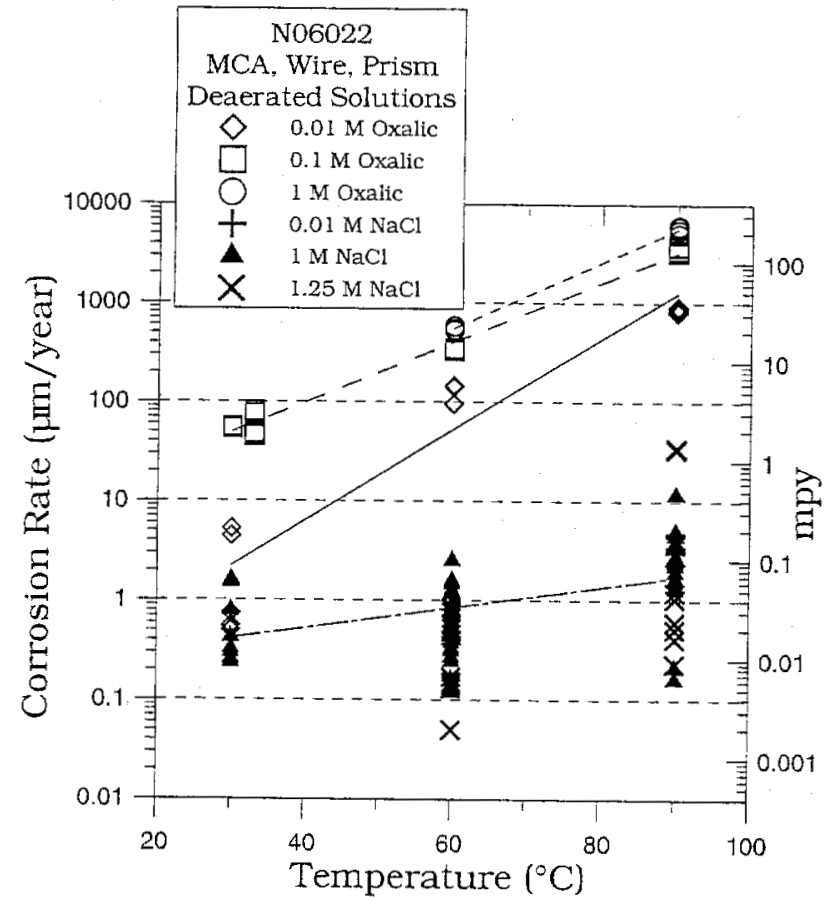

Figure 4: Corrosion Rates (PR) for Alloy 22 as a function of the temperature. 


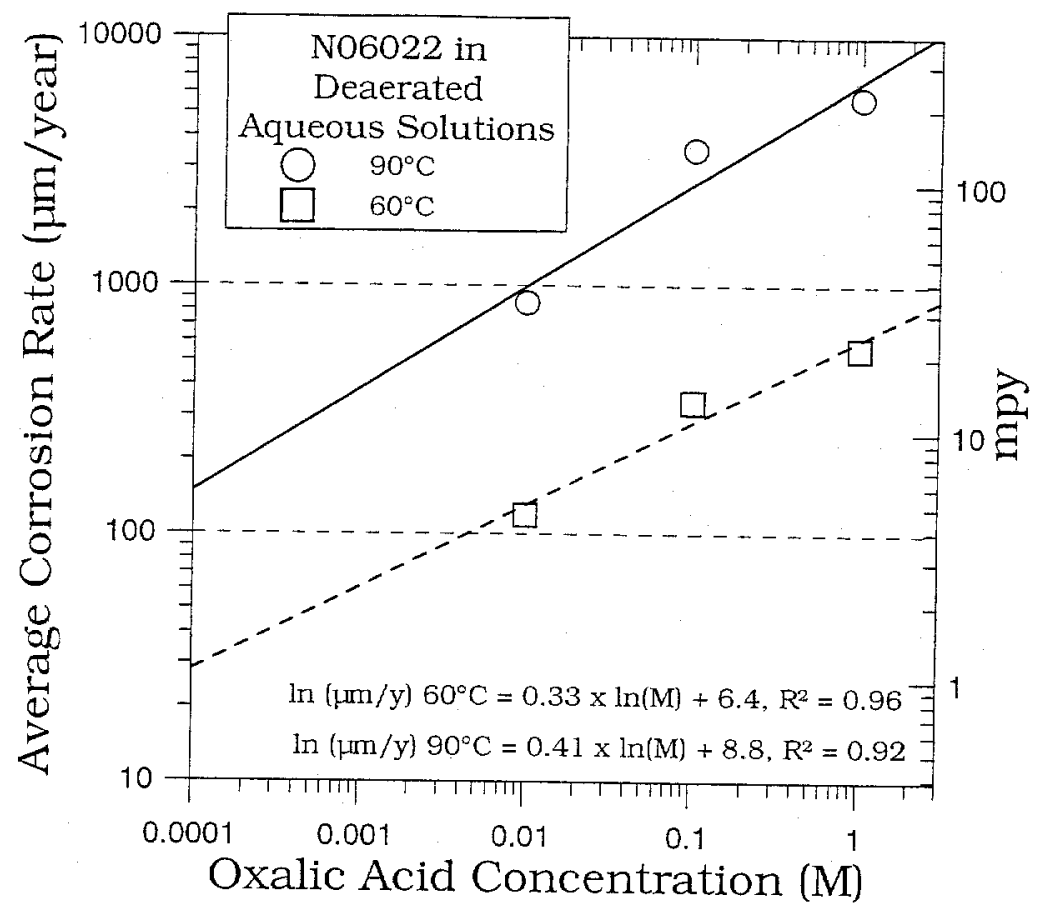

Figure 5: Average corrosion rate as a function of oxalic acid concentration.

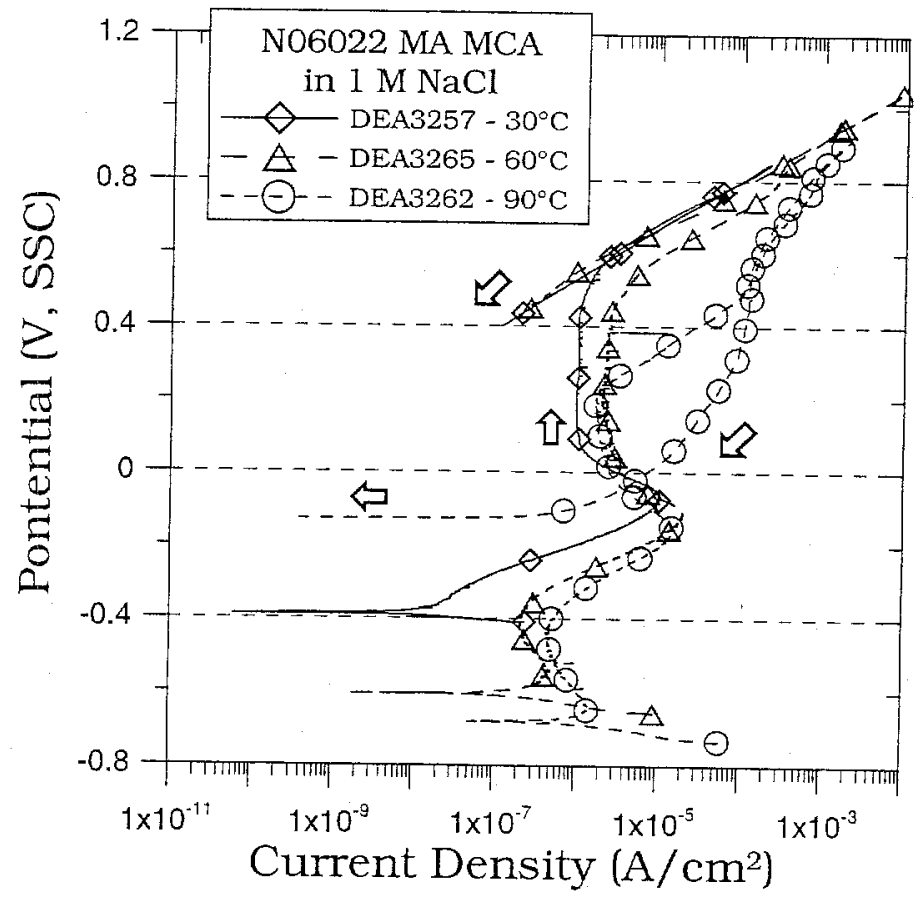

Figure 6: Cyclic polarization curves for Alloy 22 in $1 \mathrm{M} \mathrm{NaCl}$ solutions 


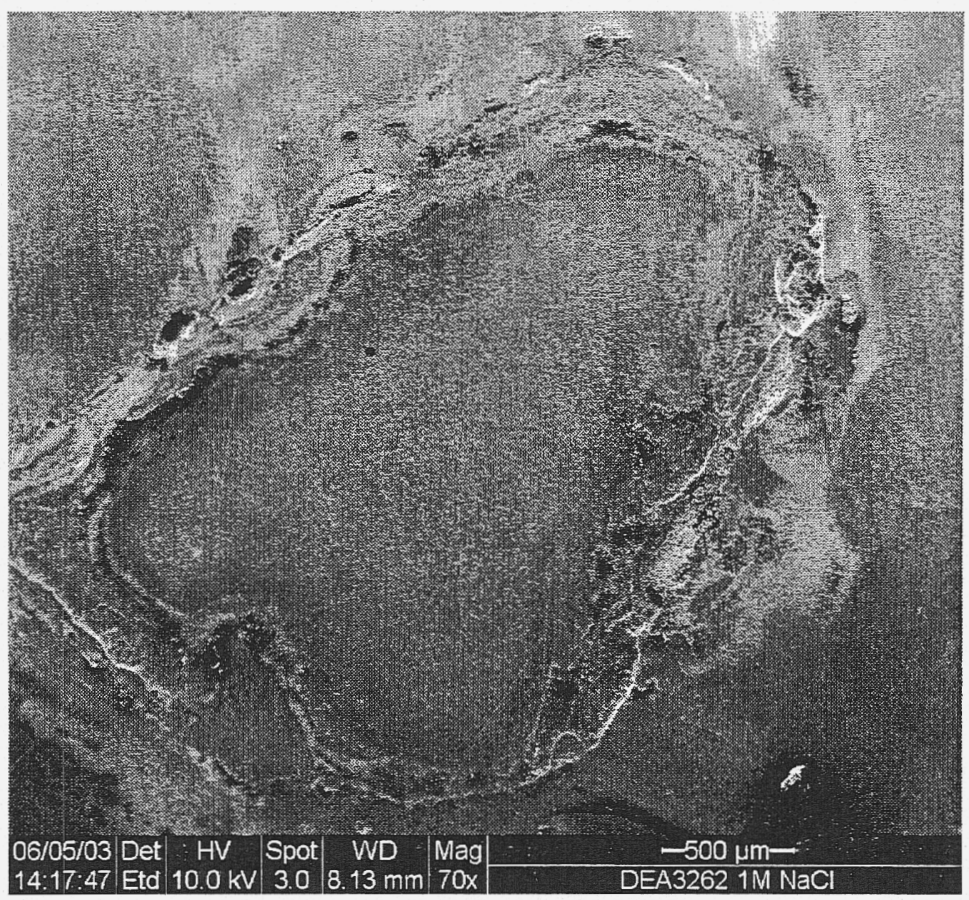

Figure 7: SEM image showing crevice corrosion in $1 \mathrm{M} \mathrm{NaCl}$ after cyclic polarization. Magnification X 70 .

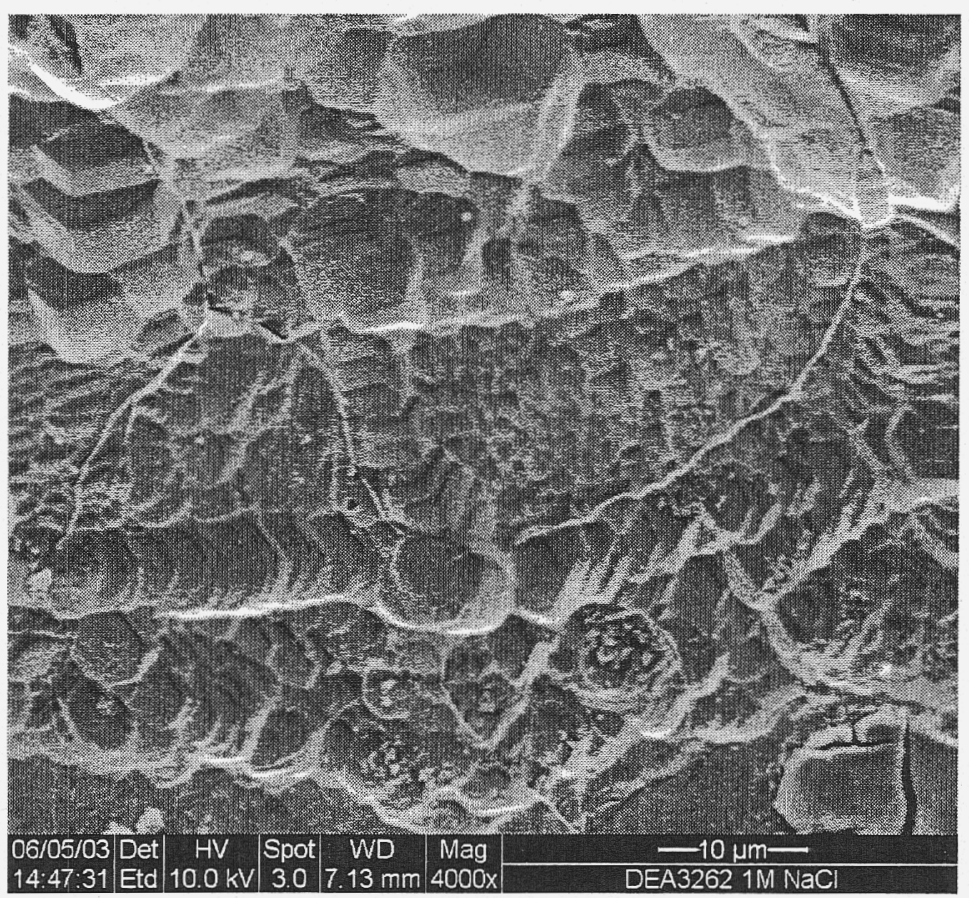

Figure 8: SEM image showing a detail of the crevice corrosion in Figure 8. Magnification X 4000. The oxide in the lower right corner was rich in Mo. 


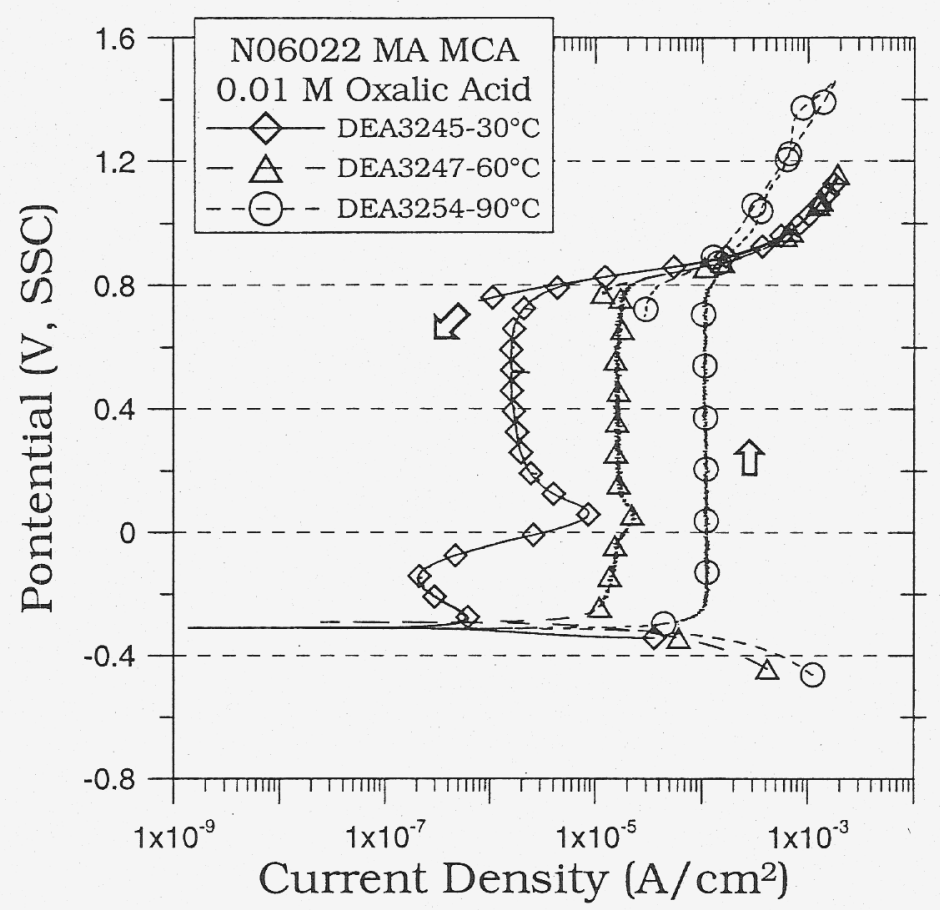

Figure 9: Cyclic Polarization curves for Alloy 22 in $0.01 \mathrm{M}$ oxalic acid

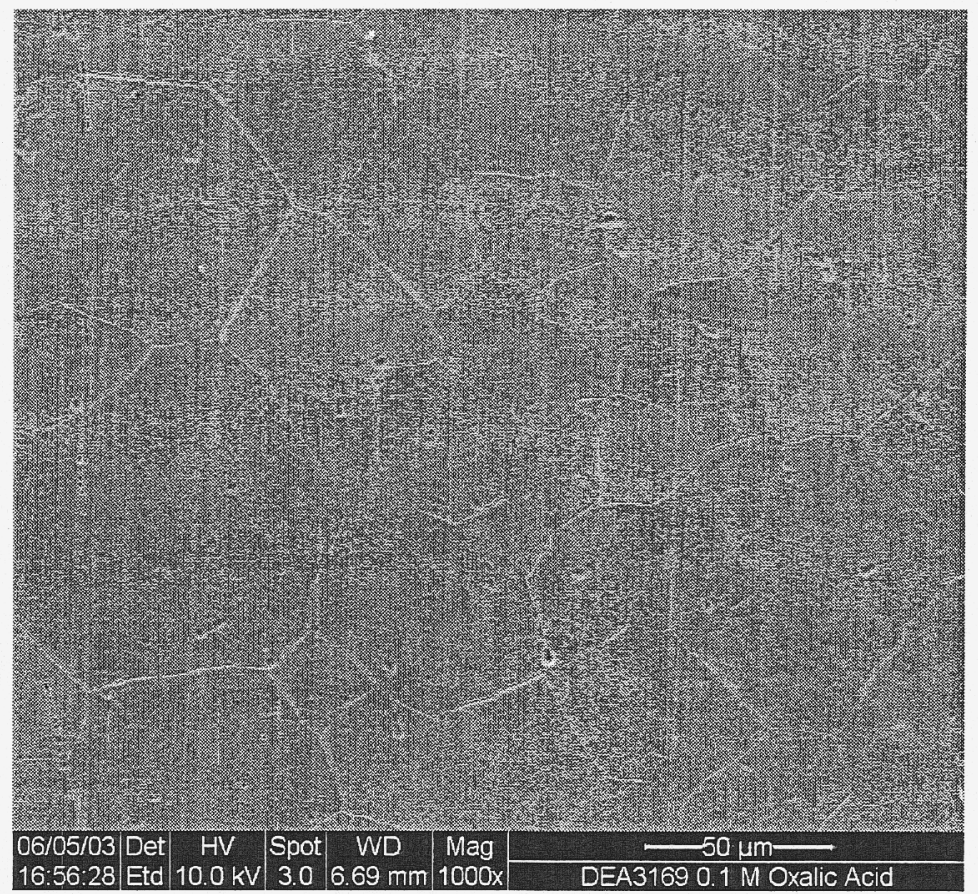

Figure 10: SEM image of sample tested in $0.1 \mathrm{M}$ oxalic acid at $90^{\circ} \mathrm{C}$ showing grain boundary etching. Magnification X 1000. 


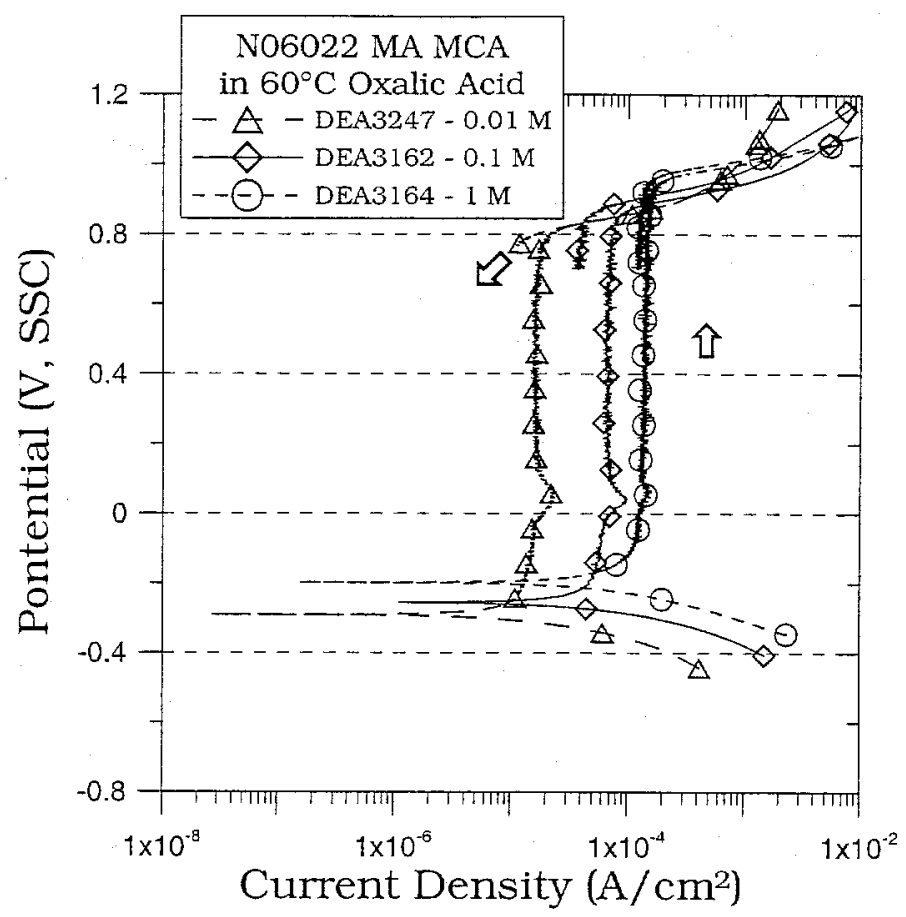

Figure 11: Cyclic Polarization curves for Alloy 22 in oxalic acid solutions at $60^{\circ} \mathrm{C}$

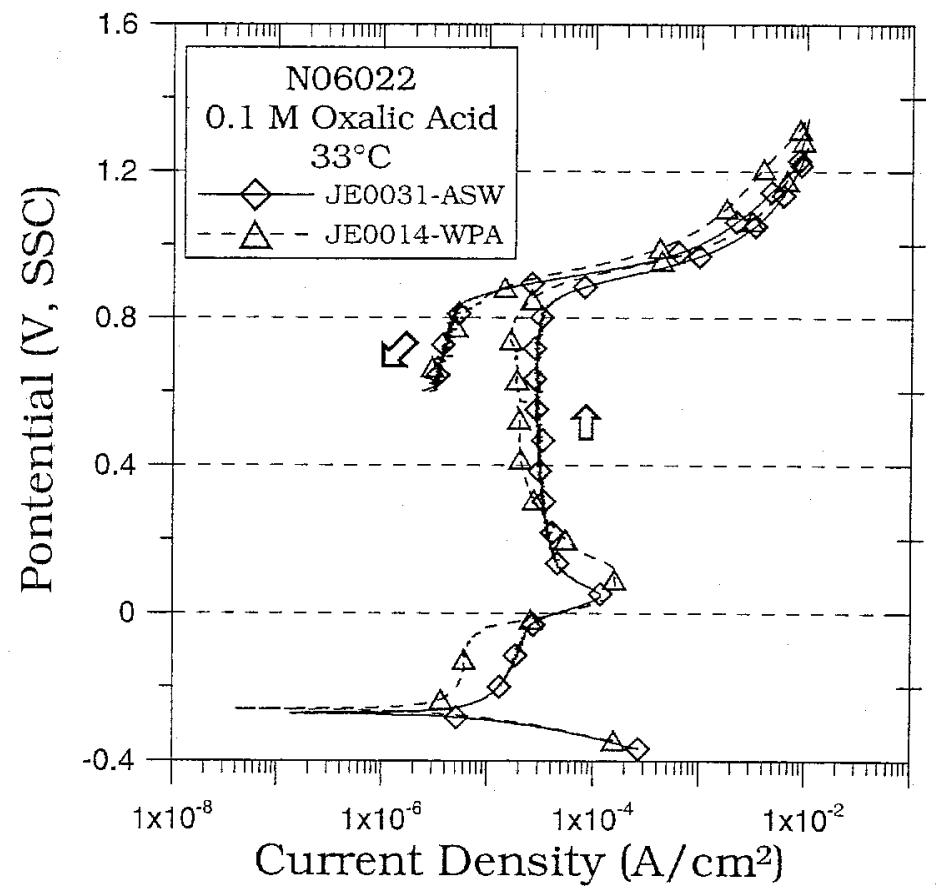

Figure 12: Cyclic Polarization curves for ASW and WPA Alloy 22 in $0.1 \mathrm{M}$ oxalic acid 


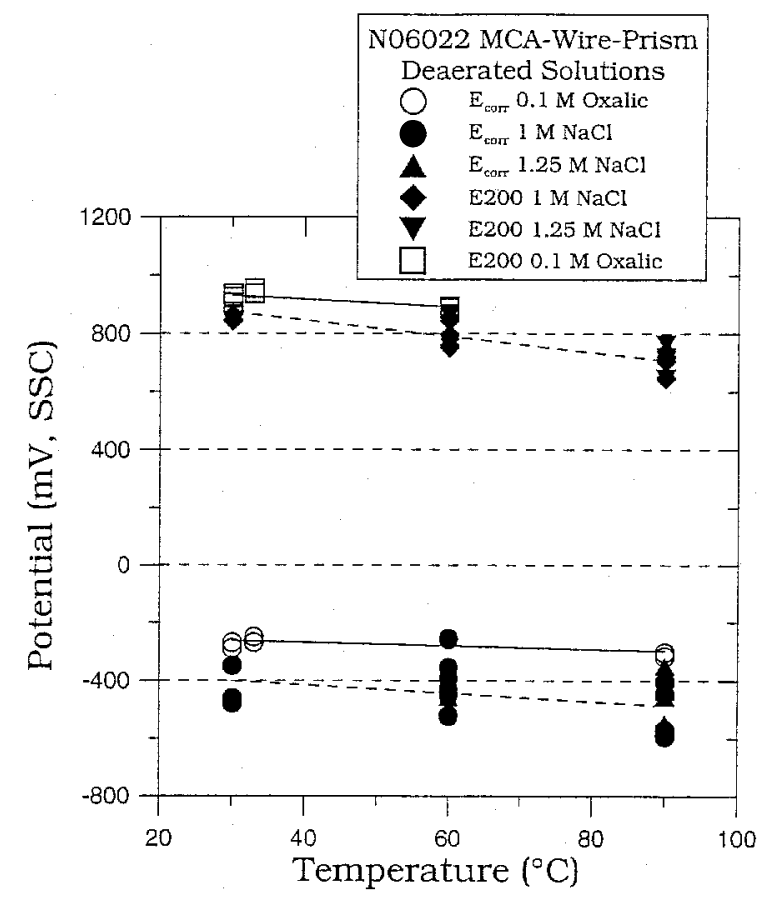

Figure 13: $\mathrm{E}_{\mathrm{corr}}$ and $\mathrm{E} 200$ for Alloy 22 in $\mathrm{NaCl}$ and oxalic acid solutions

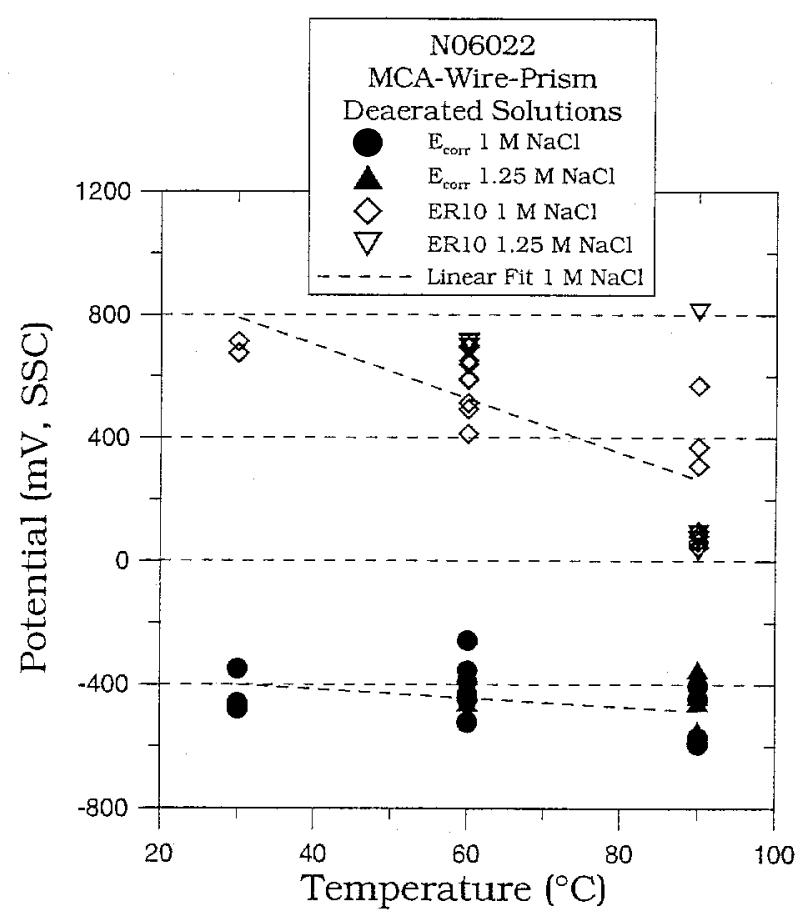

Figure 14: $\mathrm{E}_{\text {corr }}$ and ER10 for Alloy 22 in $\mathrm{NaCl}$ solutions 